\title{
IMPLEMENTASI KURIKULUM 2013 BERBASIS PENDEKATAN SAINTIFIK DALAM PENGAJARAN BAHASA INGGRIS SMA/SMK BERBASIS TEKS
}

\section{The Collaboration of Scientific Approach and Textbook-Based Approach in Teaching English for SMA/SMK: Curriculum 2013's Perspective}

\author{
Ambalegin \\ Universitas Putera Batam (UPB), Batam, Indonesia \\ e-mail: abhi140475@gmail.com \\ Suhardianto \\ Universitas Putera Batam (UPB), Batam, Indonesia \\ e-mail: suhardiantogamya@gmail.com
}

\begin{abstract}
The implementation of the Curriculum 2013 is noble because it implements attitudes, knowledge, and skills integrated in every course. The curriculum 2013 uses a scientific approach in each teaching implementation thus the students are taught to prioritize inductive compared to deductive reasoning. English, a core lesson and a skill in SMA/SMK, must be taught by teachers who have competence in transferring knowledge. But they are constrained in the application of a scientific approach to text-based English teaching (texbook-based approach). The purpose of this training is to open the horizons of English teachers in applying two approaches in teaching English at SMA/SMK level in the classroom. The method implemented was public education and training with the techniques of lecturing, discussing, and demonstrating. The result of this training was the improvement of the teachers' capability in teaching English by collaborating the scientific approach and textbookbased approach in the classroom. This training was the importance of developing the potential of students to become human beings who believe and fear God Almighty, have good morality, health, knowledge, capability, creativity, and independence, and are democratic and responsible citizens.
\end{abstract}

Keywords: curriculum 2013, scientific approach, textbook-based approach

\section{PENDAHULUAN}

Pendidikan sangat penting bagi manusia. Hampir di setiap negara telah mewajibkan para warganya untuk mengikuti kegiatan pendidikan dalam beragam teknik penyelenggaraannya, yang disesuaikan dengan falsafah negara, keadaan sosial politik, kemampuan sumberdaya dan keadaan lingkungannya masing-masing. Undang-Undang Dasar Negara Republk Indonesia 1945 pasal 13 menyatakan 
bahwa setiap warganegara berhak memperoleh pendidikan dan negara bertanggungjawab menyediakan sistem pendidikan nasional baik untuk sekolah negeri maupun swasta.

Dalam perspektif pendidikan nasional, tujuan pendidikan nasional dapat dilihat secara jelas dalam Undang-Undang Nomor 20 Tahun 2003, Bab II, Pasal 3 tentang sistem pendidikan nasional, bahwa pendidikan nasional berfungsi mengembangkan kemampuan dan membentuk watak serta peradaban bangsa yang bermartabat dalam rangka mencerdaskan kehidupan bangsa, bertujuan untuk berkembangnya potensi peserta didik agar menjadi manusia yang beriman dan bertakwa kepada Tuhan Yang Maha Esa, berakhlak mulia, sehat, berilmu, cakap, kreatif, mandiri dan menjadi warganegara yang demokratis serta bertanggung jawab (Sistem pendidikan nasional, 2003).

Sekolah sebagai lembaga dan penyelengara pendidikan dan perpanjangan tangan kebijakanan pemerintah memiliki peranan penting dalam mencerdaskan kehidupan bangsa. Proses pembelajaran yang terjadi di sekolah melibatkan beberapa elemen, seperti guru, fasilitas sekolah, murid, dan kurikulum. Guru sebagai pendidik memegang peranan penting dalam mentrasfer ilmu ke anak didik. Kompetensi guru dalam mengajarkan anak didik sangat mutlak diperlukan karena kompetensi guru adalah gambaran tentang apa yang dilakukan ketika melaksanakan pekerjaannya (Ambalegin \& Suryani, 2019). Guru harus mampu mempersiapkan diri terhadap perubahan jaman dan perkembangan teknologi. Menurut Sudjana (dikutip pada Budi, 2014) kompetensi guru merupakan kemampuan dasar yang harus dimiliki.

Kurikulum pendidikan di Indonesia sudah mengalami perubahan beberapa kali karena dunia kerja berubah sangat cepat sehingga kurikulum dapat beradaptasi dengan mengantisipasi perubahan tersebut. Kurikulum mempunyai peran dalam pembangunan pendidikan karena dalam kurikulum termaktub tujuan mulia untuk anak didik yang ingin dicapai, yaitu memberikan anak didik pengetahuan, sikap, dan keterampilan agar sesuai dengan kebutuhan kehidupan dan dunia kerja. Apalagi pada tahun 2020 hingga 2030, Indonesia akan menikmati bonus demografi, yaitu suatu kondisi dengan jumlah penduduk usia produktif 15-64 tahun mencapai titik maksimal sehingga jumlah angkatan kerja maksimal, dan bonus demografi ini akan memberikan dampak mnaksimal bila negara melakukan investasi SDM (Jati dikutip pada Winingsih, 2016).

Pemerintah menetapkan Kurikulum 2013 (K-13) pada bulan Juli 2013 sebagai langkah pengembangan KBK 2004 dan KTSP 2006. Pengembangan Kurikulum 2013 merupakan hasil kebijakan intervensi dalam rangka peningkatan kualitas pendidikan di Indonesia (Indriyanto dikutip pada Dwinuryanti, Andayani, \& Winarni, 2017). Pada Permendikbud No.70 Tahun 2013, kurikulum 2013 mengenalkan model pembelajaran pendekatan saintifik (scientific approach) (Kerangka dasar dan struktur kurikulum sekolah menengah kejuruan/madrasah aliyah kejuruan, 2013).

Walaupun telah dicanangkan Kurikulum 2013 di tahun 2013, belum semua sekolah melaksanakan Kurikulum 2013. Menurut Darmaningtyas (dikutip pada Fauzi, 2015) hanya $2 \%$ dari 6235 sekolah melaksanakan implementasi kurikulum 
2013 berdasarkan yang dibuat oleh UKP4. Menurut beberapa guru di Batam setelah dilakukan observasi dan interview, khususnya guru bahasa Inggris SMA/SMK yang melaksanakan Kurikulum 2013, pendekatan saintifik harus dilaksanakan pada pembelajaran bahasa Inggris yang dikategorikan sebagai ilmu sosial bukan mata pelajaran sains. Di sisi lain pendekatan saintifik pada Kurikulum 2013 masih melakukan pendekatan berbasis teks.

Bahasa Inggris merupakan pelajaran yang penting dan salah satu pelajaran yang di-UN-kan. Keahlian berbahasa Inggris harus dimiliki oleh anak didik sebagai pendukung ketika memeroleh pekerjaan. Batam adalah salah daerah industri yang membutuhkan banyak tenaga kerja. Di samping kemampuan vokasi, pekerja juga harus memiliki kemampuan lain seperti kemampuan berbahasa Inggris. Hal ini terbukti berdasarkan wawancara dengan staff HRD McDermott, Batam, banyak staff office yang belum mampu menulis business letter karena hal itu penting ketika melakukan koresponden kepada klien di luar negeri. Dengan kata lain keterampilan lisan dan tulisan dalam bahasa Inggris sangat penting ketika memasuki dunia kerja yang sesungguhnya (Kachru et al., 2006). Dan kunci dalam memahami Bahasa Inggris lisan maupun tulisan adalah dengan mengimplementasikannya dalam kegiatan sehari-hari di masyarakat yang berkelanjutan (Arianto, 2019).

Business writing adalah salah satu materi pada pembelajaran Bahasa Inggris di kelas 11 dan 12 SMK (KD SMK, permendikbud No 70 Tahun 2013). Anak didik diharapkan mampu membuat surat berbahasa Inggris khusus dunia usaha (correspondence). Proses pembelajaran yang dilakukan guru terbiasa mengajarkan dengan metode konvensiaonal/ceramah (pembelajaran berbasis teks). Guru menjelaskan dan 30 menit kemudian anak didik disuruh mengerjakan tugas. Beberapa anak didik bertanya dan guru membimbing, tidak lama kemudian bel tanda selesai pelajaran berbunyi. Akhirnya anak didik disuruh melanjutkan di rumah sebagai PR.

Menurut Permendikbud Nomor 103 Tahun 2014 (Kurikulum 2013, 2014), proses pembelajaran dengan metode pendekatan saintifik pada K-13 adalah;

1. Mengamati;

2. Menanya;

3. Mengumpulkan informasi/eksperimen;

4. Mengasosiasikan/mengolah informasi; dan

5. Mengkomunikasikan (Azizah et al., 2015).

Kelima elemen di atas harus diimplementasikan pada proses pembelajaran setiap mata pelajaran. Hal inilah yang menjadi permasalahan bagi guru-guru Bahasa Inggris Sekolah Theodore yaitu penerapan pendekatan saintifik dan pendekatan berbasis teks untuk pengajaran writing Bahasa Inggris di pendidikan menengah sesuai tuntutan Kurikulum 2013. Kurikulum 2013 menggunakan bahan ajar yang memungkinkan siswa berekspresi secara bebas dan kreatif melalui pilihan tugas dan teks yang bersifat aktual dan baru (new information). Di pihak guru sebagai fasilitator pembelajaran di kelas, pemberlakuan Kurikulum 2013 menuntut kemampuan guru untuk memilih dan menentukan strategi pembelajaran yang tepat (Dwinuryanti et al., 2017).

Guru Bahasa Inggris Sekolah Theodore tidak memahami penerapan materi pembelajaran Bahasa Inggris yang berbasis text sesuai dengan tuntutan kurikulum 
2013 pada pendidikan menengah. Materi pembelajaran pada Kurikulum 2013 dilaksanakan dengan penerapan pendekatan saintifik. Buku Bahasa Inggris yang disediakan sesuai dengan Kurikulum 2013 adalah buku dengan pendekatan berbasis teks. Hal ini yang sulit bagi pendidik ketika mengaplikasikan lima proses pembelajaran pada Kurikulum 2013 pada pembelajaran bahasa Inggris. Senada dengan Azizah et al. (2015), penggunaan pendekatan scientific pada pembelajaran bahasa Inggris dirasakan cukup sulit dalam penerapannya karena beberapa faktor, yaitu: 1) pendekatan scientific merupakan pendekatan baru dalam pembelajaran bahasa Inggris, 2) siswa belum terbiasa menggunakan pendekatan scientific dalam pembelajaran, sehingga dikhawatirkan hasil pembelajaran tidak optimal sehingga tujuan pembelajaran tidak tercapai.

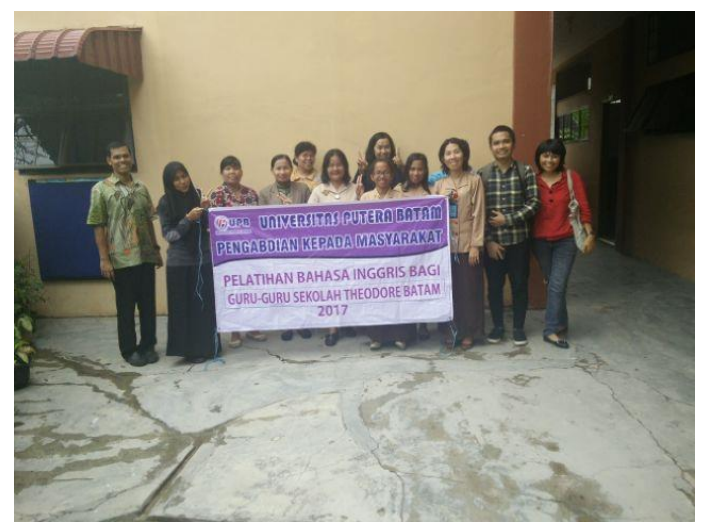

Gambar 1. Guru-guru sekolah Theodore

Guru bahasa Inggris Theodore tidak mampu menerapkan pengajaran dengan pendekatan saintifik dan pendekatan berbasis teks pada pengajaran business writing sesuai dengan tuntutan kurikulum 2013 pada pendidikan menengah. Kurikulum yang mengamanatkan esensi pendekatan saintifik tetapi kenyataannya buku-buku yang dipakai masih menggunakan penerapan pendekatan berbasis teks (Zulyetti dikutip pada Hastuti \& Muhari, 2017). Mengaplikasikan dua pendekatan sekaligus dalam sebuah proses pengajaran membutuhkan keahlian tersendiri bagi pengajar. Disisi lain, guru-guru Bahasa Inggris masih minim pelatihan penerapan pengajaran pendekatan saintifik. Hal ini yang menyebabkan masih banyak sekolah SMA/SMK di Batam menggunakan KTSP.

Berdasarkan permasalahan yang dihadapi oleh guru-guru, maka tim pengabdi melaksanakan kegiatan pembinaan dalam memecahkan permasalahan tersebut. Seperti yang disebutkan Rustanto, bahwa pembinan merupakan pemberdayaan untuk meningkatkan kepercayaan, peluang, dan kinerja warga minoritas untuk mencegah dan mengatasi masalah yang ada di lingkungannya (Nugraha et al., 2019). Tujuan dari pengabdian ini adalah untuk memberikan pelatihan penerapan dua pendekatan pengajaran pada pembelajaran bahasa Inggris khususnya materi writing sehingga dapat menciptakan suasana menyenangkan pada saat proses belajar mengajar. 


\section{METODE}

Kegiatan pengabdian yang dilaksanakan tanggal 23, 24, dan 29 Maret 2017 menggunakan metode pendidikan masyarakat (ceramah) dan pelatihan (workshop). Pelatihan pengajaran dengan menggabungkan dua pendekatan dilakukan melalui tiga tahap yang ditunjukkan pada gambar berikut ini.

\section{Analisis Situasi}
Melakukan observasi dan wawancara mendiskusikan tentang permasalahan peserta pembinaan

\section{Solusi}

Pelatihan pengajaran dengan menggabungkan dua pendekatan

\begin{tabular}{|c|c|c|}
\hline \multicolumn{3}{|c|}{ Pelatihan } \\
\hline a. Micro-teaching & $\begin{array}{l}\text { b. Workshop (ceramah } \\
\text { dan demostrasi }\end{array}$ & $\begin{array}{c}\text { c. Praktik } \\
\text { (microteaching) }\end{array}$ \\
\hline
\end{tabular}

Gambar 2. Kegiatan pengabdian

Analisis situasi mengawali pengadian ini yang bertujuan mengetahui permasalahan guru-guru dan menentukan metode yang tepat untuk mengatasi permasalah, jenis kegiatan pelatihan, materi pelatihan yang sesuai dengan kebutuhan, dan waktu dan tempat kegiatan pengabdian.

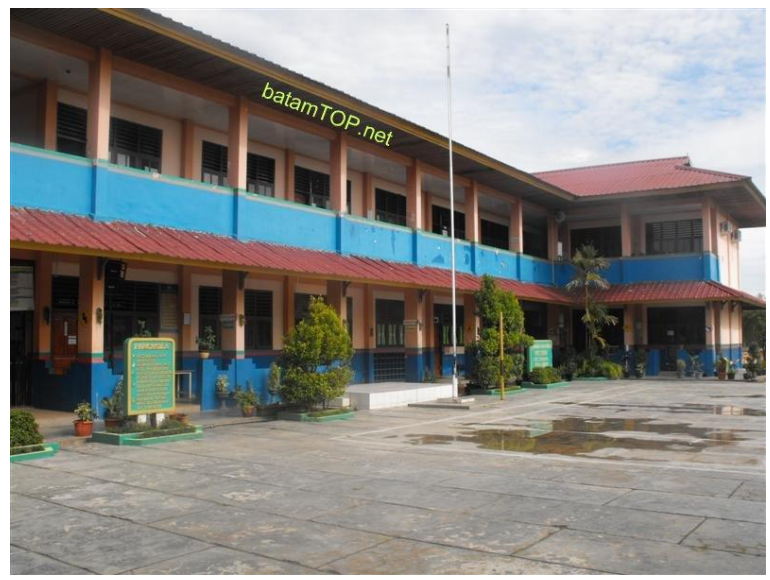

Gambar 3. Sekolah Theodore Batam

Target dari pelatihan ini adalah peserta mampu mengkolaborasikan dua pendekatan dalam proses belajar mengajar. Sebelum pelatihan, salah satu guru 
mempraktikkan pengajaran bahasa Inggris untuk mengevaluasi kekurangan dalam pengajaran Bahasa Inggris khususnya writing. Selanjutnya metode workshop diawali dengan ceramah dengan topik Business Writing dengan pendekatan saintifik dan pendekatan berbasis teks sesuai dengan tuntutan Kurikulum 2013 pada pendidikan menengah. Dengan teknik learner participation, peserta diarahkan untuk aktif bertanya dengan jawaban berupa peragaan yang dilakukan peserta. Di pelatihan hari terakhir salah satu guru bahasa Inggris melakukan praktik langsung (microteaching) di kelas dalam mengimplementasikan pembelajaran pendekatan saintifik dengan peserta lain sebagai murid. Di akhir kegiatan pengabdian peserta diminta untuk menuliskan kekurangan kegiatan pengabdian ini sebagai refleksi tim pengabdi untuk memperbaiki kegiatan pengabdian selanjutnya.

\section{HASIL DAN PEMBAHASAN}

Mitra sasaran dalam pelaksanaan pengabdian ini adalah guru-guru Sekolah Theodore yang dilaksanakan di Sekolah Theodore Jalan Raja Ali Haji Sei Jodoh Park 29-36 Batu Ampar, Batam. Guru-guru sekolah Theodore berjumlah 32 guru. Yang mengikuti pelatihan berjumlah 10 guru. Sebelum dilakukan pelatihan, salah satu guru mendemonstrasikan pengajaran yang biasa dilakukan di kelas. Selesai mendemostrasikan dapat disimpulkan pengajaran secara konvensional yang dilakukan di kelas yaitu;
a. Memberi salam
b. Membuka buku
c. Menjelaskan materi
d. Mengerjakan tugas
e. Pendekatan yang digunakan adalah textbook-based approach.

Setelah dilakukan pelatihan dengan teknik ceramah dan demonstrasi bertemakan pendekatan saintifik. Salah satu guru mendemonstrasikan pengajaran bahasa Inggris dengan materi Bussiness Writing menggunakan pendekatan saintifik. Guru dapat mendemonstrasikan proses belajar-mengajar dengan memasukkan lima unsur pendekatan saintifik yang diamati oleh peserta lain. Dari hasil demostrasi kedua peserta dimintai pendapat kelebihan dan kekurangan dari hasil demonstrasi tersebut. Peserta berpendapat penerapan pendekatan saintifik cukup efektif dan lebih banyak melibatkan siswa saat pembelajaran. Kekurangannya adalah pembelajaran dengan pendekatan saintifik ini membutuhkan waktu yang lama sementara dalam kurikulum 2013 jam pertemuan bahasa Inggris hanya dua pertemuan dan setiap pertemuan berisi 40 menit.

Pelatihan dilaksanakan di kelas di sekolah Theodore setelah jam sekolah usai. Guru selesai mengajar pukul 15.00. dan pukul 16.00 sampai dengan pukul 17.00 melaksanakan pelatihan sebanyak tiga pertemuan. Tim pengabdi sangat mengerti bahwa peserta pelatihan cukup lelah tetapi peserta tetap mengikutinya. Untuk memberi semangat peserta, tim pengabdi memberikan kudapan ringan berupa gorengan dan teh. 


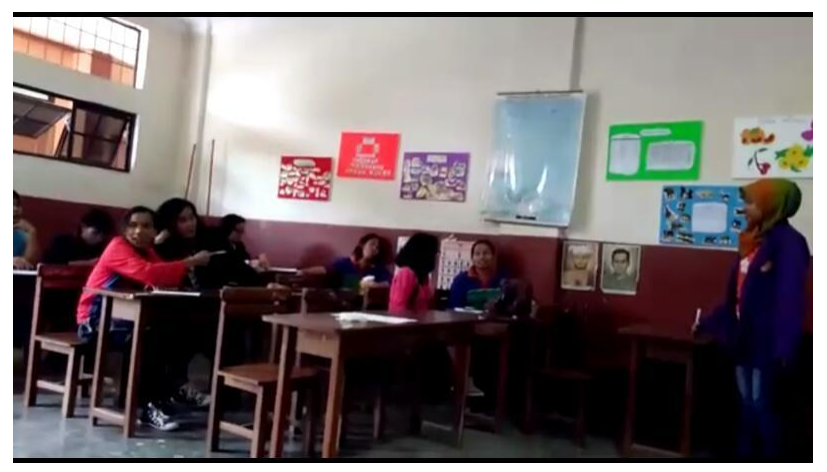

Gambar 4. Pelatihan kepada guru-guru yang dibantu oleh mahasiswi

Pada saat pelatihan tim pengabdi yang dibantu oleh mahasiswa program studi Bahasa dan Sastra Inggris memberikan langkah-langkah pelatihan teori pengajaran dengan pendekatan saintifik sebanyak 2 kali pertemuan. Teori yang diberikan untuk guru-guru adalah;

\section{Mengamati}

a. Memberikan contoh 'mengamati' pada saat memulai pembelajaran dengan cara menunjukkan gambar kegiatan di kantor (disesuaikan dengan fasilitas yang ada, misalnya: slide, gambar)

b. Memberikan contoh Business writing berbahasa Inggris.

c. Guru hanya menerangkan secara sederhana dari kegiatan yang dihasilkan pada gambar.

\section{Menanya}

a. Memberitahukan kepada guru untuk memberi waktu anak didik bertanya tentang apa yang dilihat baik faktual maupun hipotetik.

b. Guru diharapkan dengan sabar untuk menjawab. Apabila ada jawaban yang belum bisa dijawab dengan jujur guru harus memberitahu dan dicari solusinya bersama-sama.

\section{Mengumpulkan informasi}

a.Guru meminta anak didik untuk mencari informasi tentang materi pelajaran (dari buku-buku pelajaran, perpustakaan, informasi internet (jika tersedia di sekolah).

b. Anak didik dapat mencari di luar kelas (perpustakaan, lab komputer) tetap dalam pengawasan guru.

\section{Mengasosiasikan}

a.Guru meminta anak didik untuk mengelola informasi menjadi sebuah materi untuk memperluas pengetahuan.

b. Guru boleh membuka diskusi tentang informasi yang didapat antara siswa dan siswa atau siswa dan guru.

c. Guru menambahkan informasi yang didapat menjadi sebuah catatan kesimpulan dalam melaksanakan tugas selanjutnya.

d.Disamping isi materi (business writing) dan format penulisan, guru juga memberikan penambahan penulisan grammar yang benar dan kosakata berhubungan dengan business writing. 


\section{Mengkomunikasikan}

a.Guru meminta siswa untuk menyampaikan hasil informasi secara tertulis berbentuk produk (business letter)

\section{Merefleksikan}

a. Guru memberi masukan terhadap hasil pekerjaan anak didik.
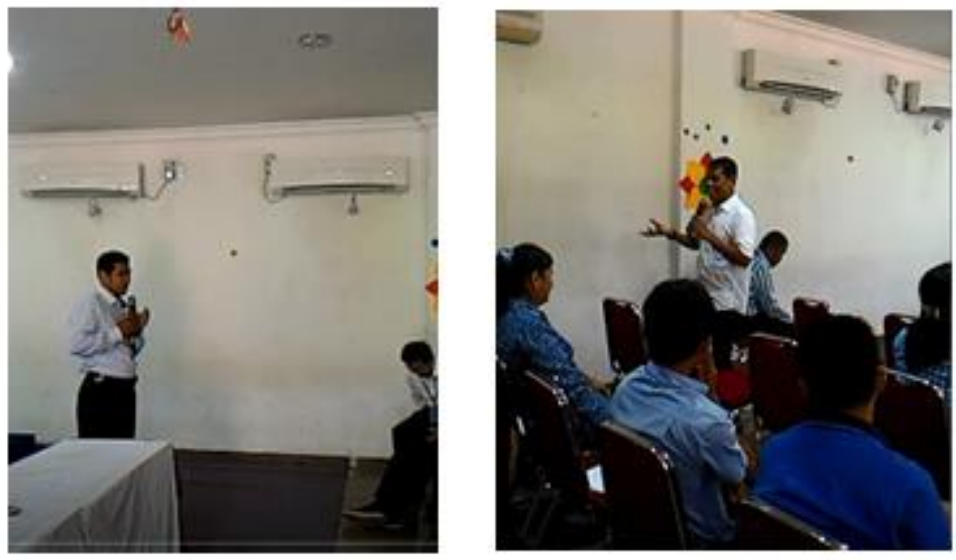

Gambar 5. Tim pengabdi melaksanakan kegiatan workshop

Tahapan pembelajaran di atas mengajak guru untuk membuat siswa aktif dalam proses pembelajaran. Guru harus mampu menggali potensi siswa melalui pengajaran dengan metode pendekatan saintifik. Karena guru terbiasa dengan menggunakan pendekatan konvensional, ketika diberikan pelatihan, guru banyak yang bertanya. Hasil dari pelatihan ini mampu membuka wawasan guru bahwasanya pendekatan ini mampu membuat siswa aktif jika diterapkan dengan benar dan dapat diaplikasikan ke pelajaran yang diampu. Kendala yang dihadapi adalah keterbatasan waktu di kelas dan minimnya fasilitas.

\section{SIMPULAN}

Pelajaran Bahasa Inggris adalah salah satu pelajaran yang penting di sekolah karena pelajaran bahasa Inggris termasuk yang diujiankan secara nasional. Pelaksanaan pembelajaran bahasa Inggris yang sesuai dan efektif akan memberikan dampak yang baik terhadap kemampuan siswa berbahasa Inggris.

Untuk itu guru harus benar-benar dan terus mencari metode pembelajaran yang sesuai dengan materi pembelajaran. Dengan melihat referensi dan pelatihanpelatihan serta saling bertukar pikiran dengan teman sejawat akan mampu menciptakan inovasi baru dalam mengajar bahasa Inggris.

Metode pendekatan saintifik pada pengajaran bahasa Inggris seyogyanya dapat menjadi pengalaman mengajarkan yang menyenangkan bagi guru dan murid dengan tidak mengenyampingkan tujuan pembelajaran itu sendiri. Dengan adanya pelatihan pendekatan metode saintifik dapat menambah wawasan guru dan pengalaman di dalam mengajar di kelas. 


\section{SARAN}

Bahasa Inggris adalah pelajaran yang penting di sekolah. Tidak hanya untuk mengejar nilai semata tetapi bahasa Inggris dapat dijadikan keahlian (skill) di masa yang akan datang. Untuk itu diharapkan semua pihak yang bertanggung jawab harus benar-benar melaksanakan tugas dan tanggung dengan baik sehingga tidak ada pihak yang dirugikan. Semua pihak seperti kepala sekolah, guru, dan stakeholder harus bekerja sama untuk meningkatkan pengetahuan guru-guru dibidang pengajaran. Pemberian pelatihan kepada guru sangatlah penting dan saling bertukar informasi tentang pengajaran sesama guru MGMP adalah kegiatan yang efektif untuk pengembangan wawasan guru sekolah dasar dan menengah di Indonesia.

\section{DAFTAR PUSTAKA}

Ambalegin, \& Suryani, M. S. (2019). Pembelajaran speaking melalui pendekatan content-based instruction bagi guru-guru SMA/SMK Harapan Batam. Jurnal PUAN Indonesia, 1(1), 19-27.

Arianto, T. (2019). Pembinaan Peningkatan English Conversation di Pantai Indah Setokok. Jurnal Puan Indonesia, 1(1), 10-18. http://idebahasa.or.id/puanindonesia/index.php/about/article/view/2

Azizah, S., Ariwidodo, E., \& Adriana, I. (2015). Implementasi pendekatan saintifik dalam pengajaran Bahasa Inggris Kurikulum 2013 di SMPN 1 Pamekasan. Okara, Jurnal Bahasa Dan Sastra, 9(2), 296-315. https://doi.org/http://dx.doi.org/10.19105/ojbs.v9i2.688

Budi, B. S. (2014). Strategi guru dalam menghadapi Kurikulum 2013 di SMA Negeri 2 Surakarta. Sosialitas: Jurnal IImiah Pend. Sos Ant, 4(1).

Dwinuryanti, Y., Andayani, \& Winarni, R. (2017). Studi kasus pembelajaran menulis teks eksposisi berdasarkan Kurikulum 2013 di Sekolah Menengah Atas. Jurnal Gramatika: Jurnal Penelitian Pendidikan Dan Sastra Indonesia, 3(2). https://doi.org/https://doi.org/10.22202/jg.2017.v3i2.2053

Fauzi, I. (2015). Studi deskripsi implementasi Kurikulum 2013 pada pembelajaran Fisika di wilayah SMA Negeri Kabupaten Bantul. Universitas Islam Negeri Sunan Kalijaga, Yogyakarta.

Hastuti, R. P., \& Muhari. (2017). Increasing procedure text reading comprehension by using the scientific approach of pictural media for students with hearing impairment. Jurnal Penelitian Dan Pengembangan Pendidikan Luar Biasa, 4(2), 96-104. https://doi.org/http://dx.doi.org/10.17977/um029v4i22017p096

Kachru, B. B., Kachru, Y., \& Nelson, C. L. (2006). The handbook of world Englishes (first edit). Blacwell Publishing Ltd.

Nugraha, A. R., Purbawasari, S., Zubair, F., \& Novianti, E. (2019). Pemberdayaan masyarakat melalui pelatihan komunikasi efektif berbasis potensi wisata dan kearifan lokal. Jurnal Pengabdian Dan Pemberdayaan Masyarakat, LPIP UMP, 3(1), 123-132.

Kerangka dasar dan struktur kurikulum sekolah menengah kejuruan/madrasah aliyah kejuruan, Pub. L. No. 70 (2013).

Kurikulum 2013, Pub. L. No. 103 (2014).

Sistem pendidikan nasional, Pub. L. No. 20 (2003).

Winingsih, L. H. (2016). Peran pemerintah daerah dalam implementasi Kurikulum 2013. Jurnal Pendidikan Dan Kebudayaan, 1(1), 37-57. https://doi.org/http://dx.doi.org/10.24832\%2Fjpnk.v1i1.226 


(2000)

